KEMAS 13 (3) (2018) 423-429
Jurnal Kesehatan Masyarakat

\title{
EFFECTIVENESS LEADERSHIP AND OPTIMALIZATION OF LOCAL POTENTIAL IN NUTRITION STATUS IMPROVEMENT EFFORT
}

\author{
Oktia Woro Kasmini Handayani ${ }^{1} \bowtie$, Sri Ratna Rahayu ${ }^{1}$, Efa Nugroho ${ }^{1}$, Bertakalswa Hermawati ${ }^{1}$, \\ Nguyen Thi $\mathrm{Vu}^{2}$, Nguyen Huu Loc ${ }^{2}$
}

${ }^{1}$ Department of Public Health, Universitas Negeri Semarang, Indonesia

${ }^{2}$ Hongbang International University, Vietnam

\section{Article Info \\ Article History: \\ Submitted February 2018 \\ Accepted March 2018 \\ Published March 2018 \\ Keywords: \\ nutrition, local, poten- \\ tial, leadership, com- \\ munity, empowerment \\ DOI \\ https://doi.org/10.15294/ \\ kemas.v13i3.13593}

\begin{abstract}
Indonesia which is a developed country, has community health issue, as nowadays face a double concern of nutrition problem. Based on the data in 2007 to 2010, over nutrition prevalence on children under five years was $14.0 \%$, increase from condition in 2007 which was $12.2 \%$, aligned with poor and malnutrition prevalence. Programs applied has not resulted nutrition status improvement as expected. The problem in this research is how does the effectiveness of community empowerment optimalization model in the effort to improve nutrition status. Qualitative approach is used to evaluate model implementation, with focus of the research is model implementation based on the input, process and output. Respondents are determined by purposive technique. While the instruments are observation guide, interview guide, and FGD guide. Analysing Technique by Miles and Huberman model. The quantitative approach, to assess model effectiveness, with data-fill form intrument. The calculation is viewed from number increase and effectiveness criteria from Sugiyono. Local potential optimalization in the effort to improve nutrition status indicate effectiveness criteria (60\%), This activity could not result maximum effectiveness level due to the leadership style tends to paternalistic which is dominated by otoritarism, causing community empowerment by cadre members and Family Welfare Program which are the potential that will be utilized can play maximum role.
\end{abstract}

\section{Introduction}

Nutrition problem is a serious concern that able to influence future development. The children with problematic nutrition status when under five years old period will affect brain development, intellegence and learning achievement thus will have more tendency to dropout school or postpond to higher grade (Ivanovic, 2008)

WHO estimates that prevalence of overweight on infant and children in 2008 reached 40 millions or $6 \%$ of world population.
The highest are on group of country having middle to high income, yet the fastest increase indeed are in group of country having middle to low income, such as Indonesia (McMurray et al, 2000; Wang, 2001)

Basic Health Research (2010) in Indonesia, the prevalence of over nutrition on children under five years was $14.0 \%$, increased from $12.2 \%$ in 2007 . In 2013 , the prevalence of poor and malnutritious children under five years was estimated to reach $19.6 \%$. Increased from $18.4 \%(4,646,933$ children) in 2007. 
Programs applied have not resulted nutrition status improvement as expected. This is due to the causes of nutrition problem are various and related with base factors, such as education and economic level requiring complicated program and long term. So that need to consider to utilize local potensial which one of it is community empowerment in order to reach program efficience and maximalize result obtained.

Local potensial is ability or power or resource owned by a region that can be developed to produce any advantage for the region (Nugroho, 2017). One research conducted in Thailand found out the presence of social capitals influencing nutrition status of children under five years. They are participation, resiprocity and proactivity of the health volunteers (Handayani, 2014). The local potensials are various between race, ethnics, tradition and socio economical condition. The variation occurs though on various region in same country, furthermore, on the same region in different time (Horowitz, 2000; Garces, 2006; Mitra, 2007). Local potention related with sosio culture on urban area (city) will be different with one on sub urban area (city outskirt), that could be due to shift of living, acculturation, education and history (Prihanto, 2010; Raharjo, 2016). Beside those, geographic condition or location is one aspect that need to be considered in the relation with community nutrition status (Fatima ON, 2011; Maria FL, 2012; Md Serajul Islam, 2014).

The research result on Semarang, located in Central Java Province, Indonesia, which is an urban region, find out that there are local potensial related with social system, culture system, social capital and influence of regional location. The social organization like IHSP (Integrated Health Service Post), willingness of community member and related institution around the community that can be involved (like university with health faculty) and the availability of supporting program "Nutrition House" (Handayani, 2016). The problem in this research is how is the effectiveness of local potensial utilization in form of optimalization of people empowerment in the effort to improve nutrition status.

Methods
The research use qualitative and quantitative approaches. Qualitative is used to evaluate model implementation, with research focus on model implementation related with input, process and output. Respondents are 7 persons consist of 1 CHSC nutrition section, 2 IHSP cadres, 2 university partnership persons and 2 mothers having children under five years. The respondents are determined with purposive technique with requirements as follow: 1) for CHSC person, has been serving for minimum 1 year, 2) for IHSP cadres, recommended and appointed by CHSC, come from unactive IHSP that reorganized, 3) volunteerly to participate in the research.

The instrument used are observation guide, interview guide and FGD guide. The analyzing technique using Miles and Huberman model. Quantitative approach is used to determine model effectiveness, through instruments of data fill form containing number of cases found, number of cases treated, number of cases counseled and number of children with improved-nutrition case. The calculation is viewed from the increase and by effectiveness criteria from Sugiyono (2014) as follow: 1) $80<\mathrm{X} \leq 100 \%$ (highly effective), 2) $60<\mathrm{X} \leq 80$ $\%$ (effective), 3) $40<\mathrm{X} \leq 60 \%$ (hesitate), 4) $20<\mathrm{X} \leq 40 \%$ (uneffective), 5) $0<\mathrm{X} \leq 20 \%$ (highly uneffective).

\section{Result and Discussion}

Overview of the researched region is densely populated area located in the middle of the city or cathegorized as urban region, consists of 3,573 families with area of 196,217 ha. Mostly senior high school graduated (32.8\%) and middle economic level. The mothers having children under five year mostly do not work (58\%) or as housewife with mostly education level senior high school graduated.

Based on deep interview, observation and FGD the results obtained are as follow: From the input, obtained that there is active IHSP cadre chief with high activities load, most of it are programs that related with health. Appointed cadre member does not actively involve yet has potensial in the activity. The existance of bureucracy among related social institution caretaker (like head of citizen association) that want to predominate so that affecting cadre's performance. 
Table 1. Quantitative Datas Result

\begin{tabular}{|c|c|c|c|c|}
\hline $\begin{array}{l}\text { Time } \\
\text { (per 3Months) }\end{array}$ & $\begin{array}{l}\text { Number } \\
\text { of Cases } \\
\text { Found }\end{array}$ & $\begin{array}{l}\text { Number of Cases } \\
\text { Treated }\end{array}$ & $\begin{array}{l}\text { Number of Cases } \\
\text { Counseled }\end{array}$ & $\begin{array}{l}\text { Number of Children } \\
\text { with Improved } \\
\text { Nutrition Status }\end{array}$ \\
\hline \multirow[t]{2}{*}{2016} & 5 & $4(80 \%)$ & 3 (outpatient) & 2 \\
\hline & & & $\begin{array}{l}1 \text { (inpatient on nutrition } \\
\text { house) } \\
80 \%\end{array}$ & $\begin{array}{l}\text { In progress } \\
40 \%\end{array}$ \\
\hline \multirow[t]{2}{*}{2017} & 8 & $7(87,5 \%)$ & 4 (outpatient) & 2 \\
\hline & & & $\begin{array}{l}1 \text { (inpatient on nutrition } \\
\text { house) } \\
62,5 \%\end{array}$ & $\begin{array}{l}\text { In progress } \\
25 \%\end{array}$ \\
\hline
\end{tabular}

$\frac{\text { Effectiveness level } \quad+60 \% \quad+7,5 \%}{\text { Source: Lamper Tengah CHSC Data and Primary Data }}$

Funding is one of the obstacle, this can be seen from some members that indirectly question reward provided by CHSC whereas the members aware that it is social activity. Or can be concluded as well that the awareness to do social work from cadres is still poor, as said by one cadre expects to get fee and transportation cost, on the other side the family of children under five years having nutrition problem look forward for aid like cash or extra fooding.

Coordination and communication between cadre and Family Welfare Program caretaker is still poor, only the chief that being active. This condition is worsen due to each cadre is difficult to contact (does not have cellphone or the cellphone does not active). So can be concluded that the chief tends to work alone, as being complained: "the other cadres are hardly cooperative, most of them refuse with various reasons".

The chief of IHSP cadre is a trustee cadre by CHSC to assist any activities related with health such as children under five years and elderly IHSP, children under five years family counseling, teenage family counseling, information and counseling centre, mosquito nest extermination, early child education post, welfare family recording, family plan counseling and oftenly awarded in IHSP administration. According to IHSP cadre chief, nearly all administration is performed alone without any support from member, as stated: "other cadres usually unactive and difficult to be asked to gather for the activity". This is contradicted with implementation of coordination and training activity where IHSP members are active and exited. It can be seen from the presence and many questions raised due to curiosity. The complain could be resulted from the chief it self who lackly delegate the tasks to the cadres. This is concluded from the chief saying: "I hesitate to ask, because the cadres will refuse and do not comply, so that on the end I will have do the job twice."

University partnership involve to counsel the activity meet some obstacles related with personal ability and student and lecture's motivation.

Implementation of an event requires better coordination, with initiate coaching and counseling from competence person. Problem faced by cadres are: 1) nescience regarding what to do, 2) has a feeling that never being involved or lack of knowledge regarding the event information, 3) has a feeling that lack of knowledge and skill thus lead to poor self confidence, 4) need to build motivation for the cadres. 7) Observation result can identify domination of IHSP chief and citizen association head, where each one willing to exhibit own role, as so affect each one leadership style and influence cadres performance. Disguised contradiction oftenly occured bring out uncomfortable circumstances. IHSP chief is unworking housewife, while citizen association head wife is a retired Public Health Office employee. On the other side, university students' skill counseling the mother of children 


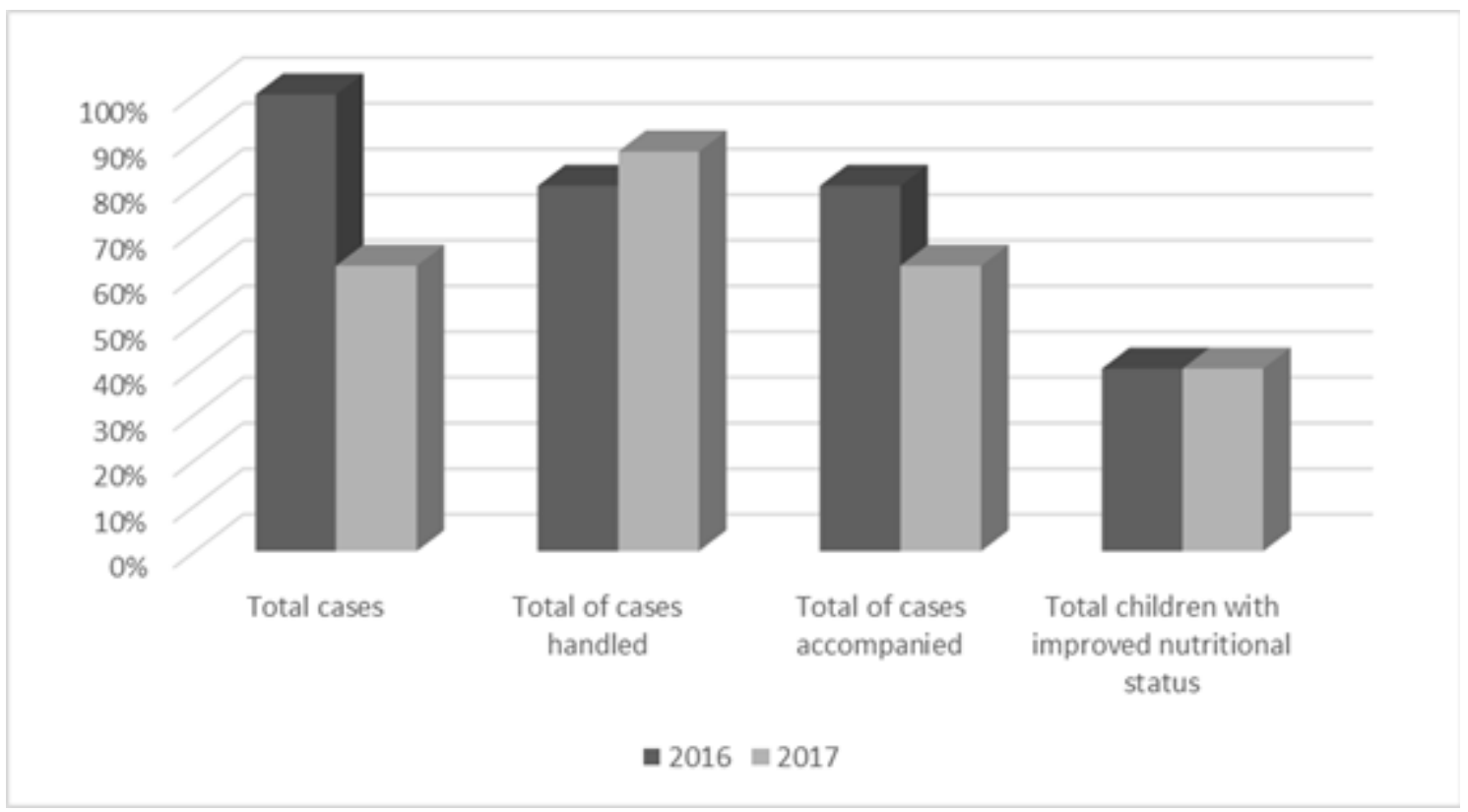

Chart 1. An Effectivity Model Description

under five years with nutrition case are very various and only few ready for field assignment. 8) Observation result also indicate that IHSP chief and cadres have poor coordination in discussing solution of occured problem. This is concluded from the statement: "We once got health record books from CHSC yet do not accordance with number of children under five, so we just go along with it."

Effectiveness level of found case is $60 \%$ (effective), meanwhile for number of treated case, counseled case and number of children with improved nutrition status are concluded as highly uneffective. Description of the result will be presented clearly on Chart 1 .

This research is by utilize the existence of IHSP, nutrition house and community empowerment consisted of health cadres, Family Welfare Program members, and university having health faculty located in the community area to become partners. The model consist of activities that represent the empowerment of each potensial owned.

Conclusion of the research indicate effective criteria $(60 \%)$ on number of cases found in 3 months. This result has not meet the expectation, which is effectiveness above $80 \%$. Number of cased found are basic to optimalize number of cases treated, counseled and number of children with nutrition status improvement. Number of case found is main part of empowerment role of cadre and Family Welfare Program member.

The leadership style of cadre's chief that process nearly all job by it self and does not involve the member much. The leadership which is a process to influence or giving example to member in order to reach shared objective does not well implemented. As cadre chief, ideally should have (1) instruction function (give task) to members as determined job description of each member, (2) consultation function (two way communication), (3) participation function (chief should be able to manage situation and involve in the event), (4) delegation function (share the task to the members) and (5) control function. Leadership style of the cadre chief can be identified as paternalistic that tends to otoritarism, from 1) more decisions are taken by the chief that consider it self as most capable and able to manage all kind of problem on field, 2) treat the member as an uncapable person in performing task, and the chief want to assist, so that it does not give necessary task to the member. Cadre chief role is an important part of successful model implementation as mention in the research by Karen (2013) that leader role in leadership support given will influence the success of health program. Leadership as a relationship system between the leader and the members is important, and proper one will give positive affect to work result (Habiba, 2013; 


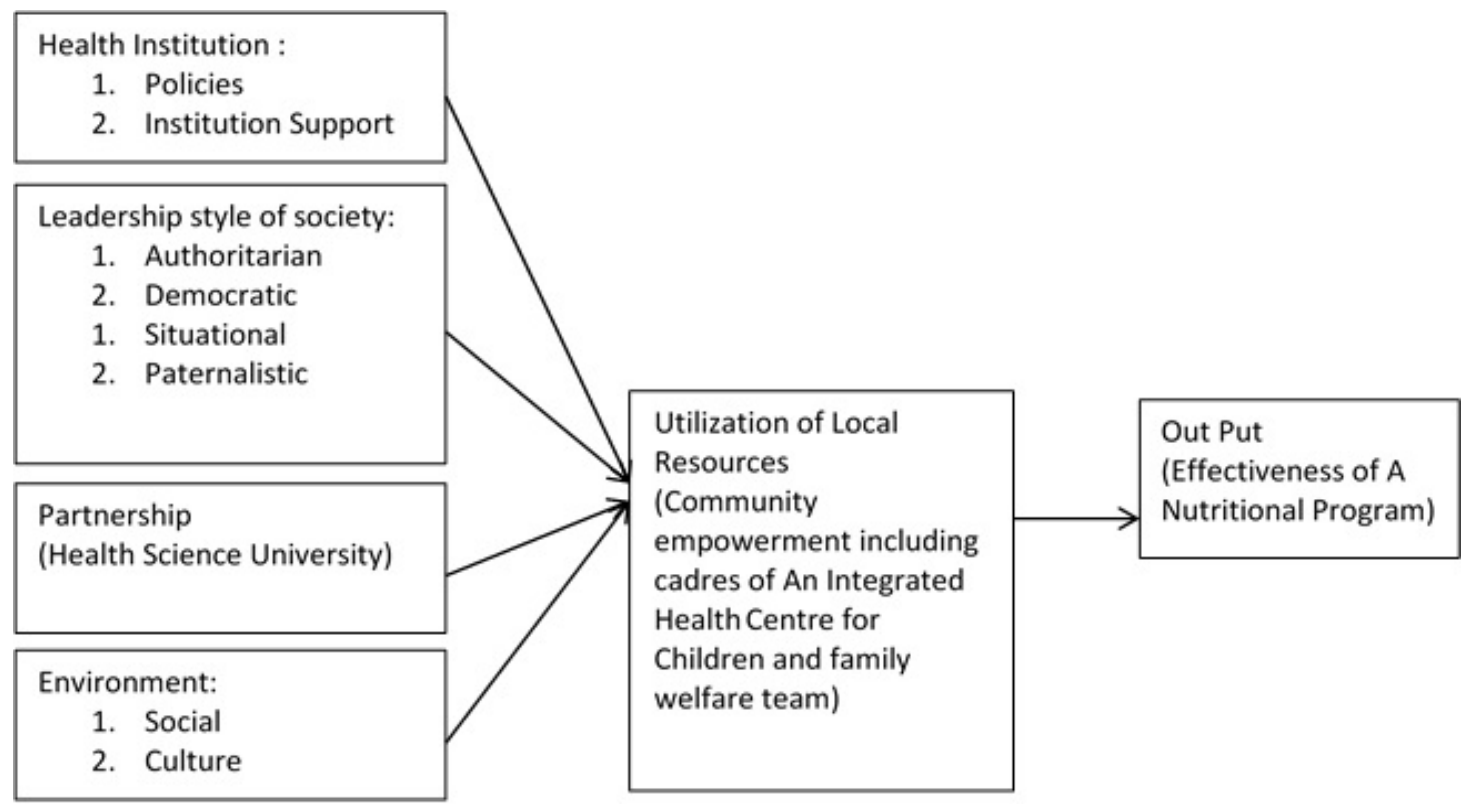

Chart 2. The Relations Diagram Refer to the Results

Osabiya, 2015).

Community empowerment by cadres and Family Welfare Program which is a potensial that will be utilized do not maximally perform the task role assigned. The potensial owned is aligned with research from De Silva (2007); Handayani (2013), mentioning that high social maternal capital and culture system owned by the mother within community network could give possitive influence to children under five years nutrition status. Other community empowerment, like in Cameron, where the effort to improve children nutrition status is done by empowering local health cadre which focusing on health mission within social groups in the community (Plan, 2009).

Cadre empowerment in this model tends to field activity, though remain being involved in program planning and evaluation, yet the role is as information source. This kind of empowerment could lead to community autonomy which one of the aspect is healthy nutritional care pattern that has an important role to overcome unsupported social factor and environment. This is aligned with research by Eileen (2007), that nutrition improvement program should also be designed and move toward community autonomy as one of the objective.

Number of cases treated, counseled and number of children with nutrition status improvement have not reached expected result. This is related with cadre's activeness and Family Welfare Program member in finding nutrition cases in the environment and is influenced by lack of communication, knowledge and motivation. On the other side, university partner involved has not yet optimally aligned with field condition. This will affect accompaniment program and determine effectiveness in nutrition status improvement. This is aligned with research result mentioning that many factors influence quality of human resources like motivation and environment whether internal or external (Nataliia, 2013; Kurtulus, 2014). Whereas HR management factor, include proper HR allocation is highly determine quality and efficiency of desired objective (Zehra, 2014; Stefane, 2006).

Intensive accompaniment and counseling from competent person on the beginning of an activity is a must to do in order to be able to utilize existing potensial, including cadre chief who willing to work hard and cadre member who willing to participate in the activity. These has been applied in accompaniment practise by some institution along with the recent development and requirement to improve the potensial and achivement of given task and responsible (Ismail, 2009; Bozionelos, 2004; 
Inzer, 2005). Though the institution in this research is a social one, yet the accompaniment principle is required. Accompaniment model is a task performed by facilitator that able to do as supporter, activator, catalisator and motivator, while the primary actor in the activity is the stake holder it self. Accompaniment program should have clear objective without leaving profesionalism principle (Nail H, 2007; Julio, 2012). Accompaniment is one strategy that could decide the achievement of a program and community development to reach maximum objective need to be accelerated with the present of a companion (Budiyanto, 2011). Accompanion system or mentoring could improve performance including the achivement and avoid overspend of cost and time (Joy, 2006). The relations diagram refer to the results as follow:

Outline of the nutritional program effectiveness which is an output from local resources utility model in this research as community empowerment including cadres and family welfare team. It's depend on health institution, leadership style in community, partnership, culture, and their environment.

\section{Conclusion}

Optimalization of local potensial in the effort to improve nutrion status indicate effective criteria $(60 \%)$ on cases number found within 3 months. This result has not meet expected one, which is above $80 \%$ effectiveness. Number of cases found is a base to optimalize number of cases treated, counseled and number of children with nutrition status improvement. Number of cases found is part of main role of empowerment by cadres and Family Welfare Program members. This activity can't not resulting maximum effectiveness level due to the leadership style tends to paternalistic that dominated by otoritarism, causing community empowerment can not perform the role maximally as assigned task. Leadership as a relationship system between the leader and the member is important and the proper on will contribute a positive impact to the work result. Other obstacle is related with partner weakness involved that required motivation, field skill and partner internal regulation that bonds the members.

\section{Acknowledgment}

The acknowledgment is delivered to Ministry of Research, Technology and High Education that has fond the research, Semarang Health Office that has given the permision and assistance to this research, Lamper Tengah and Mijen CHSC Head and staff that has facilitated data collection.

The gratitude is also delivered to IHSC cadres, Family Welfare Program members, the mothers and Faculty students involved and Mr. Sofwan Indarjo SKM, M.Kes as the counselor

\section{References}

Bazionelos Nikos. 2004. Mentoring Provided: Relation to Mentors Career Success, Personality, and Mentoring Received, 64: 2446.

Budiyanto H. 2011. Pendampingan Dalam Proses Perencanaan Partisipatif Program Penataan Lingkungan Pemukiman Berbasis Komunitas (PLPBK). Jurnal Local Wisdom, 3(1): 34-40.

De Silva, M.J., Harpham T. 2007. Maternal Social Capital and Child Nutritional Status in Four Developing Countries.Helath Place, 13(2): 341-355.

Eileen SA, Richard AW, Janet RW. 2007. Self Regulation, Self Efficacy, Outcome Expectations, and Social Support: Social Cognitive Theory and Nutrition Behavior. Ann Behav Med, 34(3): 304-312.

Fatima Omer Nabag. 2011. Comparative Study of Nutritional Status of Urban and Rural School Girl's Children Khartoum State, Sudan. Journal of Science and Technology, 12 (02):6068.

Garces, I. C., Scarinci Isabel C, Harrison Lynda. 2006. An Axamination of Sociocultural Factors Associated With Health and Health Care Seeking Among Latina Immigrants. Journal Immigrant Health Vol 8, 377-385p.

Habiba Anwar. 2013. Impact of Paternalistic Leadership On Employees Outcome- A Study On The Banking Sector of Pakistan. IOSR-JBM, 7(6): 109-115.

Handayani, Oktia Woro Kasmini. Raharjo, Bambang Budi. 2016. Perencanaan Program Gizi Berbasis Potensi Lokal (Studi di Daerah Urban dan Sub Urban). Laporan Penelitian, LP2M Universitas Negeri Semarang.

Handayani, Oktia Woro Kasmini. Sunaryantro, Lasmono Tri. Farida, Eko. 2013. The Contribution of Cultural System in Todler Parenting by Mother (In the Context of Nutrition Status). Research on Humanities and Social Sciences, 3(6):105-111.

Handayani, Oktia Woro Kasmini. Rahayu, Tandiyo. 
Budiono, Irwan. Hunnirun, Pomsuk. Tomee, Songpol. Hansakul, Anong. 2014. Social Capital and Nutritional Status of Child Under 5 Years in Rural Indonesia and Thailand. Kemas, 10(1): 88-95.

Horowitz, C. R., Davis, M. H. etc. 2000. Approaches to Eliminating Sociocultural Disparities in Health.Health Care Financing Review 21 (4): 57-72p.

Inzer Ionnie D, Crowford.C.B. 2005. E Review of Formal and Informal Mentoring: Processes, Problems, and Design. Journal of Leadership Education, 4(1):31-50.

Ismail. A, Khian Jui.M.K, Abdullah.M.M. 2009. Formal Mentoring, Gender, Type and Mentorship and individuals, Phsycosocial: A Moderating Model Approach. Pakistan Journal of Commers \& Social Sciences, 3: 1024.

Ivanovic, D., Rodriguez, Perez, H. 2008. Twelve-year Follow-up Study of The Impact of Nutritional Status at The Onset of Elementary School on Later Educational Situation of Chilean School-age Chieldren, European Journal of Clinical Nutrition 62, 18-31p.

Joy Penman, Frances White. 2006. Peer Mentoring Program Pop-Up Model For Regional Nursing Student. Journal of University Teaching and Learning Practis, 3(2): 123-135

Julio J Ramirez. 2012. The Intentional Mentor: Effective Mentorship of Undergraduate Science Students.The Journal of Undergraduate Neuroscience Education, 11(1): A55-A63.

Karen Milner et al. 2013. The Relationship Between Leadership Support, Workplace Health Promotion and Employee Wellbeing in South Africa. Health Promotion International, 30(3): 514-522.

Kurtulus Yilmaz Genc. 2014. Environ Mental Factors Affecting Human Resources Management Activities Of Turkish Large Firms. International Journal of Busines and Management 9(11): 102-122.

Maria Fernanda Laus, et al. 2012. Geographic Location, Sex and Nutritional Status Play an, 0(0): 1-7Important Role in Body Image Concerns Among Brazilian Adolescents. Journal of Healtf Psychology.

McMurray RG et al. 2000. The Influence of Physical Activity, Socioeconomic Status, and Ethnicity on The Weight Status of Adolescents. Obesity Research, 8:130-139.

MD. Serajul Islam, Jakia Sultana Jothi, Monirul Islam, and A.K. Obidul Huq. 2014. Nutritional Status of Rural and Urban Under-five Children in Tangail District, Bangladesh. International Journal of Innovation and Applied Studies, 8(2): 841-848.

Mitra, M., Sahu, P. K. etc. 2007.Nutritional and Health Status of Gond and Kawar Tribal Pre-school Children of Chhattisgarh, India. Journal Hum. Ecol, 21 (4) : 293-299p.

Nail Hamilton and Lisa Montpetit B. 2007. Fostering Profesionalism Through Mentoring. Journal of Legal Education, 57(1):1-29.

Nataliia Hunko. 2013. Factors Influencing The Formation of Human Resources. Economic \& Sociology 6(2); 65-72.

Nugroho, Efa. Shaluhiyah, Zahroh. Purnami, Cahya Tri. Kristawansari. 2017. Counseling Model Development Based on Analysis of Unwanted Pregnancy Case ini teenegers. Jurnal Kemas, 13 (1).

Osabiya. B, Ikenya. E. 2015. The Impact of Leadership Style On Employees Performance In An Organization. Public Policy and Administration Research, 5(1): 193-205.

Plan. 2009. Community Approaches to Child Health in Cameroon: Applying the Community-Based Integrated Management of Childhood Illness (c-IMCI) Frameworks. Rhode Island, USA.

Prihanto Teguh. 2010. Perubahan Spasial dan Sosial Budaya Sebagai Dampak Megaurban di Daerah Pinggiran Kota Semarang.Jurnal Teknik Sipil \& Perencanaan 1(2): 131-140.

Raharjo, Bambang Budi, Handayani, Oktia Woro Kasmini. Nugroho, Efa. Hermawati, BK. 2016. Local Potentials as Capital for Planning Nutrition Programs for Urban Fringe Areas in Developing Countries.Pakistan Journal of Nutrition, 15: 1026-1033

Sugiyono, P.D., 2014. Populasi dan sampel. Metode Penelitian Kuantitatif, Kualitatif dan R\&D.

Stefane M Kabene, et.al. 2006. The Importance of Human Resources Management in Health Care: A Global Next. Human Resources For Health 4(20): 1-17.

Wang Y. 2001. Cross-national Comparison of Childhood Obesity: The Epidemic and The Relationship between Obesity and Socioeconomic Status. International Journal of Epidemiology, 30:1129-1136.

Zehra Alakoc Burma. 2014. Human Resource Management and Its Importantce For Today's Organizations. International Journal of Education and Social Science 1(2): 85-9. 